\title{
An Essay on B.S. Johnson: Brian Castro's Drift
}

\section{Marilyne Brun}

\section{(2) OpenEdition}

\section{Journals}

Electronic version

URL: https://journals.openedition.org/ces/8577

DOI: $10.4000 /$ ces. 8577

ISSN: 2534-6695

\section{Publisher}

SEPC (Société d'études des pays du Commonwealth)

\section{Printed version}

Date of publication: 1 September 2009

Number of pages: $34-44$

ISSN: 2270-0633

\section{Electronic reference}

Marilyne Brun, "An Essay on B.S. Johnson: Brian Castro's Drift", Commonwealth Essays and Studies [Online], 32.1 | 2009, Online since 23 December 2021, connection on 17 February 2022. URL: http:// journals.openedition.org/ces/8577 ; DOl: https://doi.org/10.4000/ces.8577

\section{(c) (i) (5) $\Theta$}

Commonwealth Essays and Studies is licensed under a Licence Creative Commons Attribution - Pas d'Utilisation Commerciale - Pas de Modification 4.0 International. 


\section{An Essay on B.S. Johnson: Brian Castro's Drift}

The main character of Brian Castro's fifth novel, Drift (1994), is a fictional double of British experimental novelist Bryan Stanley Johnson (1933-1973). The latter's presence in the novel, visible through Castro's exploration of Johnson's literary ideas, poses the question of the novel's relation to the essay. Drift can be regarded as a reflection on B.S. Johnson's literary ideas and on Tasmanian Aborigines by way of B.S. Johnson.

The architects can teach us something: their aesthetic problems are combined with functional ones in a way that dramatises the crucial nature of their final actions. B.S. Johnson (“Introduction” 16)

7 he work of British writer Bryan Stanley Johnson (1933-1973) can be regarded as a series of experimentations with the genre of the novel.

In the introduction to his collection of short stories, Aren't You Rather Young to Be Writing Your Memoirs?, Johnson deplored "the incomprehension and weight of prejudice which faces anyone trying to do anything new in writing" (31). This incomprehension, he continued, "is enormous, sometimes disquieting, occasionally laughable," so much so that his novel Trawl was shelved in the Angling section in one of his major booksellers (ibidem). Contemporary Australian novelist Brian Castro (b. 1950) similarly remarked that his novels are often misunderstood and put on the wrong shelf in bookshops: "My novels Birds of Passage and Double-Wolf are frequently found in certain bookshops under the category of Wildlife and Nature. They are never sold there. My novel After China once appeared on the Travel shelves, and did quite well" ("Auto/biography" 105). Humorous though Castro's remark may be, the mistakes of booksellers are but a fragment of the incomprehension that Johnson deplored in his introduction. The two novelists share more than erroneous shelf classification. Both Johnson and Castro are perceived as "difficult" writers who seek to develop the genre of the novel in innovative ways. It is perhaps Castro's shared frustration and empathy with Johnson that prompted him to stage the writer as the main character of his fifth novel, Drift (1994). It starts with a preface which introduces the life and work of B.S. Johnson:

B.S. Johnson [...] was a little known though important British author who dared reassess the novel form. [...] Johnson was shabbily treated by many of his literary contemporaries. Overcome by immense depression, perhaps on account of the death of his mother ('Em' or 'Emily'), he took his own life on 13 November, 1973, in London. (vii-viii)

The author of the preface - a certain Thomas James McGann, who readers later learn is a character of the novel - then moves on to explain that Johnson's suicide and unfinished trilogy were starting points for the novel. In this sense, the preface 
adds a significant layer of complexity to readers' understanding of Drift, since it clearly distinguishes the British writer Bryan Stanley Johnson from his fictional double in Drift, Byron Shelley Johnson. ${ }^{1}$

Drift is the story of 'Byron Shelley' Johnson, who travels to Tasmania some twenty years after the death of Bryan Stanley. Castro's decision to change Johnson's first names and to locate him in Tasmania long after the death of the British writer posits a problematic relation between the real-life Johnson and his fictional other in Drift. The relation is of a critical nature, for the fictional Byron Shelley allows Castro to experiment with Johnson's literary ideas. Thus, Drift can be regarded as an essay on Johnson's own texts. Moreover, the double displacement imposed on the historical character of B.S. Johnson - his change of name and setting allows Castro to develop a reflection both on Johnson's literary ideas through the fictional Byron Shelley, and on the plight of Tasmanian Aborigines by way of B.S. Johnson. While the genre of the essay appears recurrently in Castro's work, none of his novels comes closer to the essay than Drift.

The plot of Drift starts in London, where Byron Shelley is receiving letters from a Tasmanian Aboriginal woman, Emma, with whom he falls in love. When Emma accuses him of being all words and no action, like most writers, Byron Shelley decides to leave both his mother and his mother country to travel to Tasmania. There, he goes on a boat trip and meets Emma's twin brother, albino Aborigine Thomas McGann. As Byron Shelley imagines the violence of Tasmania's colonial past and of the lives of Emma and Thomas's ancestors, he slowly elaborates his suicide, which involves blowing up the caves below Cape Grim where Tasmanian Aborigines were massacred by European settlers in 1828. There are three main narrators: the second part is narrated by Byron Shelley and Thomas's ancestor Sperm McGann, while the third part is narrated by Thomas McGann. ${ }^{2}$ For readers familiar with Johnson's life - a man who certainly never went to Tasmania - Castro's plot seems comical, if not completely absurd. Yet beyond the droll tribulations of Byron Shelley in Tasmania, Castro's character is clearly inspired by Bryan Stanley. In his biography of Johnson, Jonathan Coe presents the writer as a man dedicated to "literal truth" (339) and convinced that writing could only come from personal experience (145). ${ }^{3}$ With his working-class background Johnson was, according to Coe, "aggressively proletarian" (140) and an unlikely match for

1. In the interest of clarity, I will refer to Castro's fictional character as "Byron Shelley". Castro seems to have chosen "Byron" and "Shelley" for phonetic reasons. Bryan/Byron and Stanley/Shelley are near rhymes. Byron is a phonetic reminder of Bryan (Johnson) and of course Brian (Castro). "Byron" and "Shelley" also refer to the Romantic poets, and point to the character's romanticism in the novel.

2. Narrative voices are ambiguous throughout Drift. For instance, Byron Shelley at times narrates Sperm's life and at other times enters his narrative.

3. Coe's biography of Johnson was published ten years after Drift, and therefore contains a wealth of information which would not have been available to Castro when he was writing the novel. My references to Coe's biography refer to general and accepted elements 
his upper middle class wife, Virginia Kimpton (140). Johnson was particularly attached to his mother, and was deeply affected by her death in December 1971. Coe concludes that Johnson was a sensitive and vulnerable man who felt isolated as an experimental writer and depressed by the lack of the recognition which he felt he deserved. Drift's Byron Shelley experiences the same feelings in London. Born in a working-class family, he is married to Ainslie Cracklewood, an upper class woman who acts as a patron for his writing. Drift includes several (fake) reviews of Byron Shelley's work, which highlight his alienation as an experimental writer and critics' total misunderstanding of his work and aspirations. Byron Shelley's mother is also central to his life, and he commits suicide shortly after her death in the novel. However, Johnson's suicide is reinterpreted in Drift. While Johnson most probably committed suicide in 1973 because of a nagging depression due to his lack of literary recognition, the death of his mother and the breakdown of his marriage, in the novel Byron Shelley's suicide is a political, cultural and even literary act to free the ghosts of history in Tasmania.

Byron Shelley evokes all of Bryan Stanley's works as his own. The plot of Drift includes references to the loose chapters of The Unfortunates (13) and the holes in Alberto Angelo (174), while House Mother Normal is hinted at (199). ${ }^{4}$ However, Johnson's works are not confined to giving Byron Shelley some level of biographical authenticity - they are actually central to an understanding of Drift. ${ }^{5}$ References to Trawl are of particular significance. Trawl is Johnson's account of a three-week trip which he undertook on a fishing trawler in the Barents Sea, where he reminisces about his relationships with women. In Drift, Byron Shelley similarly goes on a trip around Tasmania and reminisces about his past relationships. Castro seems to have based his choice of title on Trawl. Both "trawl" and "drift" are one-word, one-syllable titles associated with the sea. Just like Johnson in Trawl, Castro playfully uses the polysemy of "drift" in his novel. Byron Shelley "drifts into his narcolepsy" (233), his jaw has "a slight sardonic drift" (63), not to mention Castro's references to driftwood and his playful "if you get my drift" at the end of the novel (266). While "trawl" works as an extended metaphor for the workings of the mind in Johnson's novel (Guignery 94), "drift" similarly acts as a metaphor for Byron Shelley's life and literary work in Castro's text. Trawl also hints at some of Castro's motivations for choosing Byron Shelley's first names in the novel. Coe argues that the main issue in Trawl is the ideal of romantic love (226). In this light, it is possible to understand Drift as a novel on

about Johnson's life and work, and do not mention Coe's conjectures on Johnson's latent homosexuality or fascination with the Muses.

4. The plot of Drift also stages Byron Shelley working for Stromboli - an element of the plot of Travelling People - and experiencing the life of a supply teacher - a period of Johnson's life which he explores in Albert Angelo. The idea of counting points developed in Johnson's Christy Malry's Own Double-Entry is also present in Drift.

5. The following paragraphs point to links between Johnson's novels and Drift which are not intended as exhaustive but as points of reference for my argument. 
the ideal of romantic love, which is represented by the impossible relationship between Emma and Byron Shelley. The centrality of romantic love to the plot is thus put forward in the character's first names, Byron and Shelley, two of the most prominent representatives of Romanticism. ${ }^{6}$

Without a doubt, the most significant work of Johnson's in Drift is the first volume of his unfinished trilogy, See the Old Lady Decently. The preface of Drift introduces Johnson's plans for a trilogy and explains that the writer only completed the first volume. In See the Old Lady Decently, Johnson invited reader participation in the rest of the trilogy in a fictional conversation between a hypothetical reader and himself: "[Reader:] It would be just like your sort to go so far as to invite reader participation in the remaining two volumes of the trilogy! / [Johnson:] What a very relevant idea!" (109). Johnson's invitation is partly taken up in Drift, whose structure matches the unfinished trilogy. Drift is divided into three parts. The first part, which has no title, is a short passage from See the Old Lady Decently which - Castro thought - described Tasmania. The second and third parts bear the titles of the last two volumes of Johnson's trilogy: "Buried Although..." and "Among Those Left Are You...". 7 If the structure of Drift suggests that the novel could be a sequel to Johnson's trilogy, several elements indicate that Drift is less a sequel than a critical examination of the literary ideas that Johnson wanted to explore in his trilogy.

Drift develops a few themes and events that Johnson set out to write on in the trilogy, including his visit to Ypres, where his grandfather died during World War I, and motherhood, a central notion in the novel. However, the centrality of Johnson's mother in See the Old Lady Decently is removed and replaced by a focus on Byron Shelley in Drift. There is also little continuity in style or voice between Johnson's first volume and Drift: Castro does request reader participation and deploys metafictional devices, yet there is little experimentalism in the novel. The unusual structure of See the Old Lady Decently, which contains a variety of parts that all have a specific title (year (age), V, H, GB, BB, N, O, poem and various letters), ${ }^{8}$ is not present in Drift. The BB ("Broader Britain") sections, which are thematically closest to Drift, are full of ellipses and contain no names: "Perhaps the most situated town in all the, how is it that it is clearly not further? / It is due to the mixture of. [sic]" (62). Such devices, which Johnson used "to give generality, if not universality" (quoted in Bakewell 10), are absent in Drift, which deals with the specific context of Tasmania. In this light, Drift centres less on continuing Johnson's trilogy than on exploring his ideas on "truth". In

6. Byron Shelley is characterised by "a massive, debilitating romanticism" (32-33), which suggests that he is a "romantic" parody of Johnson (Lo 71).

7. Drift adds a level of interpretation to the titles: Johnson referred to his (already buried) mother in the titles, but Drift's second part, "Buried Although...", clearly refers to Johnson's own death and the continuation of his work through others such as Castro.

8. See Bakewell's introduction to the novel for more details on the meaning of these titles. 
the preface, McGann recalls Johnson's words on truth: "Telling stories really is telling lies... I am not interested in telling lies in my own novels" (vii). ' Johnson's commitment to truth, McGann explains, articulates the plot of Drift: "This then, was a point of departure for me. It hung upon this thesis: that if Johnson declared that everything he wrote was the truth, then his obviously fictional works, his most defensively imaginative creations, would entail the complete fulfilment of his projections" (viii). Johnson's notion of truth has puzzled critics to this day. Based on a commitment to use autobiographical material, Johnson's concept of truth is really a matter of rendering his own perceptions and feelings about life, with all the confusion, anarchy and subjectivity that perceptions imply. As Guignery points out, Johnson's commitment was not without its contradictions, since he used fictional devices in all of his works (124). The plot of Drift is based on these limitations. Starting from the premise that Johnson wrote only truth, Castro forces the fictional Byron Shelley to experience everything that he wrote, and conversely to experience more in order to be able to write. ${ }^{10}$ Indeed Byron Shelley feels bound to go to Tasmania because Emma has accused him of being all words and no action. So that when he says that Emma's letter "reads like a prophecy" (9), he refers less to uncanny foretelling than to what he regards as the obligation for the written word to be experienced. Byron Shelley thus posits a necessary correspondence between the world of the senses and the world of literature.

Philip Pacey has suggested that B.S. Johnson was a prisoner of his own theory, while Patricia Waugh has argued that his commitment was detrimental to his literary work (Guignery 281). Castro, however, goes further by suggesting that his commitment to truth was not only detrimental to his literary work, but also to his life. He explains Byron Shelley's suicide as an unavoidable consequence of his intellectual commitment, one which was not sustainable as a literary project. Byron Shelley - and by extension B.S. Johnson - was inevitably drifting (pun intended) towards suicide because of his literary ideas. As a playful enactment of Johnson's artistic preoccupations, Drift is halfway between fiction and the essay: it is a reflection on B.S. Johnson and writing which combines a fictional narrative with an exploration of Johnson's literary project.

This tension between fiction and the essay in Drift is articulated around a specific figure of speech. Right at the beginning of the novel, Byron Shelley writes: "The magazine of which I'm currently the editor will at least make some appropriate noise, postmodern perhaps, having believed I was really dead all these years anyway" (8). Indeed, the missing link between Byron Shelley and Johnson

9. Castro does not indicate that this is a direct quote from Johnson's work, so that references to "Johnson" in Drift can always ambiguously refer to Byron Shelley and/or the real-life Johnson.

10. I use the word "truth" in Johnson's sense, that is to say, to designate a real-life experience. 
is death, which is clear in Castro's use of the prosopopoeic trope in the novel. Prosopopoeia involves attributing a fictional speech or discourse to an absent, inanimate or dead other; inanimate objects or dead people are presented as acting, talking, walking, responding (Fontanier 404). The presence of Byron Shelley in the novel is clearly a prosopopoeia: the dead Johnson is brought back to life some twenty years after his death in a different context. And it is the prosopopoeic trope which allows Castro to experiment with Johnson's literary ideas, situating the novel at the crossroads between fiction and the essay.

The language of the novel, then, is a double discourse. As Fromilhague suggests, prosopopoeia is "a trope of double language" (my translation) which contains within it a literal and a metaphorical meaning (104). Unlike most tropes, which usually have a metaphorical meaning only, the meaning of the prosopopoeic trope can only be found after a process of re-interpretation (ibidem). Prosopopoeia, she continues, introduces a form of fictitious dialogue between the living and the dead (105). The first sentence of Drift reads: "Let me get to the point immediately: I've always wanted to compose my own obituary" (7). The sentence contains a literal meaning: a man wants to compose his own obituary. Yet, considering that the dead B.S. Johnson is speaking, it also contains a second layer of meaning: Johnson ironically says that he would like to compose his own obituary postmortem. Drift, therefore, contains an extended double discourse. Readers can follow the plot at a literal level, or take into account the subtext of the life and literary ideas of real-life Johnson. Prosopopoeia in the novel is not a straight-forward case of intertextuality, but really a form of double discourse, a hybrid construction in the Bakhtinian sense ${ }^{11}$.

So that when Byron Shelley says "Life isn't a book, take my advice" (7), readers are confronted with two utterances: the utterance of the narrator, which seems general and almost proverbial, as well as an intertextual reference to Johnson, which suggests that writing truth in novels is ultimately impossible. The combination of these two discourses throughout the novel makes its narration hybrid. As Castro himself argued: "The prosopopoeic encapsulates the project of hybridity[,] the crossing of two worlds and two genres" ("Auto/biography" 121). In this sense, prosopopoeia articulates the tension between fiction and the essay in the novel, and is a trope based on a mechanism of hybridity. However, the complexity of the prosopopoeic trope extends beyond the voices of Byron Shelley and Bryan Stanley. There is another level to the prosopopoeia, another voice behind theirs in the novel.

In an essay entitled "Auto/biography", Castro mentions the prosopopoeic trope in relation to Drift. Interestingly however, his references to prosopopoeia

11. According to Bakhtin, "a hybrid construction is an utterance that belongs, by its grammatical (syntactic) and compositional markers, to a single speaker, but that actually contains mixed within it two utterances, two speech manners, two styles, two 'languages', two semantic and axiological system beliefs" (304). 
do not refer to the presence of the dead Johnson in his novel, but rather to what he calls his "lament" for Tasmanian Aborigines:

In [Drift], I wanted to 'hear myself speak' as it were, casting a dead author in my voice in order to lament the literal death of a culture, the Tasmanian Aborigines. [...] The prosopopoeic trope, which is the fiction of an apostrophe to an absent, deceased or voiceless entity, which posits a possibility of the latter's reply and confers upon it the power of speech, restores mortality. This fictional address from and to the dead, or as De Man has it, a voice-from-beyond-the-grave, is an engraving or graphein, my lament for the genocide of the Aboriginal people of Tasmania. (“Auto/biography” 118-120)

As Castro argues, Byron Shelley embodies the plight of Tasmanian Aborigines in Drift. The dead Johnson brought back to life in the character of Byron Shelley (first level of the prosopopoeia) performs a "fictional address from and to the dead" that mourns the genocide of Aborigines in Tasmania (second level of the prosopopoeia). How exactly Byron Shelley embodies Castro's lament for the genocide of Tasmanian Aborigines is rather subtle. Towards the end of the novel, Byron Shelley literally changes skin colour: he has been injecting himself with copper and becomes darker and darker. His change of skin colour is often interpreted by critics as an attempt to resemble Tasmanian Aborigines and thereby experience their reality. Yet the text of the novel makes it clear that Byron Shelley's change of skin colour does not have anything to do with passing as Aboriginal. When Thomas McGann suspects that Byron Shelley is trying to look Aboriginal and reminds him that Tasmanian Aborigines are no longer black, the British writer agrees with him, explaining that "the intensity serves its purpose" (207). Byron Shelley sheds his racial status of White, yet the blackness of his skin does not signify Aboriginality, but a form of resistance to whiteness and authority. Indeed Byron Shelley is first mistaken for Salman Rushdie - not an innocent comparison on Castro's part - and is then compared to a Jamaican, a West African, anyone but a Tasmanian Aborigine.

Inscriptions of race are very ambiguous in Drift (and in Castro's work as a whole). The third part of Drift is narrated by Thomas McGann, an Aborigine who "began writing the last part of Johnson's trilogy" (172). A Tasmanian Aborigine, McGann is paradoxically albino. Whiter than white Australians, McGann's skin colour mirrors the contradictions within his own identity and challenges his loyalty to the different colour groups (Daniel 23). If McGann's Aboriginal heritage is invisible, Byron Shelley's British heritage similarly becomes invisible as he gets darker. His blackening metaphorically resembles ink. ${ }^{12}$ Considering that Byron Shelley has stopped writing by the time he starts his injections, the process can be regarded as the progressive writing in, or even writing out, of

12. My thanks to Claire Omhovère for suggesting possible parallels between Byron Shelley's injections and ink. I would also like to thank Vanessa Guignery for her helpful suggestions. 
Byron Shelley himself, writing being transferred onto his very body.

Neither British nor Aboriginal, Byron Shelley is perceived as a single representative of his own group, just like McGann. Byron Shelley and McGann clearly work as doubles in the novel. Both are writers, have a relationship with Ainslie Cracklewood, and experience the death of their (step)mothers. So that Byron Shelley and McGann almost seem to be one and the same person, a schizophrenic doubling of one person into two antithetical (black-white) others. Perhaps Deakin, an immigration officer, was right to think that Byron Shelley was one of the impersonators and forgers "who change their looks, their names, their skin, even their personalities" (94, my emphasis). The following passage presents Byron Shelley's motivations for changing skin colour. The protagonist feels that his skin "has silenced the inauthentic, endowed a potential simply for actions, not words. [...] Extinction. No longer white, unquestioning, biblical. No more dreams of primogeniture and ownership. No longer an author. What a relief" (209). Byron Shelley's change of skin colour, then, is related to writing: his skin allows him to give up "words" and focus on "actions". The passage equates authorship with authority and thus whiteness. Its combination of anaphora and parallelism ("no longer white", "no longer an author") establishes a direct link between skin colour and writing. Perhaps Castro is hinting at the voicelessness of non-whites in literature, pointing to the overwhelming whiteness among Australian writers and the problematic status of non-white writers in Australia. For Byron Shelley, the association between whiteness and authorship means that his dark skin colour releases him from the responsibility of writing. His change of skin colour, then, involves adopting a position towards writing. His dark skin allows him to stop writing, not only since authorship is linked with whiteness, but also since, as I suggested earlier, his darkening can represent a transfer of writing onto Byron Shelley's body itself. This is precisely where the link between Byron Shelley and Tasmanian Aborigines lies. What the writer and Tasmanian Aborigines have in common in the novel is extinction. Byron Shelley belongs to a now extinct breed - that of novelist -, whereas Tasmanian Aborigines faced genocide. While the writer imagines (and hence is forced to experience) the lives of Emma and Thomas's ancestors and therefore revives these lives through narration, he also personifies their extinction. What Castro establishes is a series of parallels between the impossibility of Johnson's literary project and the genocide of Aborigines in Tasmania. In this sense, Castro explores the plight of Tasmanian Aborigines by way of B.S. Johnson.

Bernadette Brennan has summarised Drift as "a narrative concerned with erasure, the erasure of the writer, a race of people and of writing itself" (39). The erasure of the writer and Tasmanian Aborigines is indeed recurrently addressed in similar terms in the novel. The figure of the writer is repeatedly presented as deceased, or even extinct. At the beginning of the novel, Byron Shelley states that he wanted to become a novelist: "No, not a famous novelist, but one who was true to the idea, someone who didn't feel the need. And nowadays at least, 
someone who was extinct" (7-8, my emphasis). The word "extinct" appears in a very different context a few pages later: "At London University, attending nighttime lectures, I learnt about extinction. Unicorns, native Tasmanians, the frenzy of purity and cleansing during nationhood" (32). Thomas McGann also refers to "the constant extinction of [him]self" (193). Writers and Tasmanian Aborigines are characterised in similar terms through the repetition, in different contexts, of the word "extinct". Castro thus posits a direct link between the extinction of the writer, the destruction of the true artist and the extinction of Tasmanian Aborigines. Historically, Tasmanian Aborigines were declared an extinct group by colonial authorities after the death of Truganini in 1876. As Ryan argues, authorities were keen to describe her as the last Tasmanian Aborigine and to talk about the extinction of the "race" because without Aborigines there can be no issues of land rights or settlement (255). However, many Tasmanians have mixed Aboriginal ancestry. While some families are recognised as descendants of Tasmanian Aborigines, other groups claiming Aboriginal ancestry still lack official recognition in Tasmania. The claim that Tasmanian Aborigines were extinct represents a linguistic and discursive erasure of the existence of their mixed-race descendants, which constitutes, in Spivak's words, "an epistemic violence" on them (quoted in Barlow 59). The extinction of Tasmanian Aborigines, then, is both physical and linguistic.

This is where fascinating parallels between Byron Shelley and Tasmanian Aborigines can be established. Towards the end of the novel, Byron Shelley becomes "extinct" in racial terms. As he injects himself with substances, he is increasingly perceived as a separate species: "no one could see him, as though their gazes fell away at the appearance of an extinct species" (255). Byron Shelley is thus doubly extinct: as a writer committed to writing the truth and as the only representative of his race. His darkening paradoxically makes him invisible to others: "He says they don't call him Mr Johnson anymore. They don't call him anything. They don't even see him" (225). Byron Shelley is invisible to white Tasmanians since he cannot fit in known categories. Nearly extinct physically as the last and only representative of his group, he is also extinct linguistically since he cannot be named. Even more striking is the fact that Byron Shelley cannot be seen. Tasmanian Aborigines were removed from the Tasmanian mainland to Flinders Island in the nineteenth century: removed from the everyday life of European settlers, they were visually erased as a group. The impossibility to call, name or see Byron Shelley thus represents the visual and linguistic erasure of descendants of Tasmanian Aborigines in the nineteenth century. Byron Shelley's disappearance, like that of Tasmanian Aborigines, is enacted visually and linguistically before his actual physical disappearance. The plight of Tasmanian Aborigines is thus symbolically dramatized in the impossibility of Johnson's literary project. Their fate is addressed indirectly through aesthetic means: the political issue is allegorically represented through Johnson's predicament as a writer. As we have seen, Castro's indirect approach to the Tasmanian Aborigines 
is made possible by a double prosopopoeia - the dead Johnson being brought to life as Byron Shelley and representing the plight of Tasmanian Aborigines. It is the aesthetic approach to these issues which allows Castro to enact what he calls the "morality of style" ("Auto/biography" 120).

It may be useful here to return to the opening quote of this paper: "The architects can teach us something: their aesthetic problems are combined with functional ones in a way that dramatises the crucial nature of their final actions". Johnson admired the ability of architects to combine aesthetics and functionality in order to enhance effect. It seems that Drift enacts Johnson's suggestion to associate the functional with the aesthetic. ${ }^{13}$ The novel addresses the issue of the Tasmanian Aboriginal heritage through the aesthetic conundrums of B.S. Johnson's work. More than just staging B.S. Johnson, Drift is structured around his literary ideas. The novel weaves fundamental links between authorship, colonialism and skin colour, so that it is not only an imaginative work of fiction, but also an obituary, a lament and an essay on B.S. Johnson and the plight of Tasmanian Aborigines.

Drift is a somewhat ambiguous obituary for Johnson. The novel celebrates his literary oeuvre, his dedication to developing the genre of the novel, and his persistence in the face of criticism. Yet it also rejects Johnson's central concept of truth as a possibility in literature. So that Johnson, a man who was committed to telling the truth in his novels and who rejected the "lies" of fiction, is paradoxically commemorated in a work of fiction. The fictionality of Drift is particularly extreme: first because of the double prosopopoeia, but also because of Byron Shelley's change of skin colour and of the intricate pattern of doubles that run throughout the narrative. In this sense, the hyper-fictionality of Drift acts as Castro's assertion of his own commitment to fiction in literature. Indeed, Castro presents all of his works as fiction, so that even Shanghai Dancing, a novel largely based on autobiographical material, is playfully described as a "fictional autobiography" (book jacket, my emphasis). In this respect, Johnson is central to Castro's sense of identity as a writer, and Drift represents Castro's celebration of Johnson's significance to his own work. This is perhaps not so remote from the legacy that Johnson hoped to leave: "I write perforce for myself, and the satisfaction has to be almost all for myself; and I can only hope there are some few people like me who will see what I am doing, and understand what I am saying, and use it for their own devious purposes" ("Introduction" 29). Drift is a subtle response to Johnson's plea, for it engages in a dialogue with Johnson's ideas while subverting them for Castro's "own devious purposes."

Marilyne BRUN

\section{Université Toulouse II - le Mirail and The University of Melbourne} Works Cited

BaKewell, Michael. "Introduction". See the Old Lady Decently. London and New York:

13. Johnson's words are also particularly appropriate to discuss Castro's After China, which addresses architecture itself as a combination of aesthetics and functionality. 
Viking Press, 1975. 7-14.

Bakhtin, Mikhail. The Dialogic Imagination: Four Essays. 1981. Trans. C. Emerson and M. Holquist. Austin: U of Texas P, 1998.

Barlow, Damien. "Authenticity/Hybridity and Pallawah Identities in Castro's Drift." Southerly 58.2 (Winter 1998): 59-66.

Brennan, Bernadette. "Drift: Writing and/of Annihilation." Southerly 60.2 (Winter 2000): 39-50.

Castro, Brian. Birds of Passage. 1983. London: Angus and Robertson Sirius, 1989.

—. Double-Wolf. Sydney: Allen \& Unwin, 1991.

—. After China. 1992. Adelaide: Lythrum Press, 2003.

—. Drift. 1994. Port Melbourne, Vic.: Minerva, 1995.

—. "Auto/biography". Looking for Estrellita. Queensland: Queensland UP, 1999. 98-123.

-. Shanghai Dancing. Artarmon, NSW: Giramondo, 2003.

Coe, Jonathan. Like a Fiery Elephant: The Story of B.S. Johnson. London: Picador, 2004.

Daniel, Helen. "Outside the Prison of Logic: An Interview with Brian Castro." Island 59 (Winter 1994): 20-29.

Fontanier, Pierre. Les Figures du discours. Paris : Flammarion, 1977.

Fromilhague, Catherine. Les Figures de style. Paris : Armand Colin, 2005.

Guignery, Vanessa. Ceci n'est pas une fiction: Les Romans vrais de B.S. Johnson. Paris : PU Paris-Sorbonne, 2009.

Johnson, Bryan Stanley. Travelling People. Constable: London, 1963.

—. The Unfortunates. 1969. London: Picador, 1999.

-. Christie Malry's Own Double-Entry. London: Collins, 1973.

-. "Introduction". Aren't You Rather Young to Be Writing Your Memoirs? London: Hutchinson, 1973. 11-31.

—. See the Old Lady Decently. New York: Viking Press, 1975.

-. Omnibus: Alberto Angelo, Trawl and House Mother Normal: A Geriatric Comedy. London: Picador, 2004.

Lo, Miriam. “'Possible Only on Paper?' Hybridity as Parody in Brian Castro's Drift." Journal of Australian Studies 65 (2000): 69-74.

Ryan, Lyndall. The Aboriginal Tasmanians. Second Ed. St Leonards, NSW: Allen \& Unwin, 1996. 